Karolina Stanilewicz

Akademia Sztuk Pięknych im. Władysława Strzemińskiego

w Łodzi

\title{
Zabytkowe hafty norbertanek żukowskich. Stan badań po czterdziestu latach
}

Wśród nielicznych rozpoznanych zabytków pochodzących z klasztornych pracowni hafciarskich ważne miejsce zajmują szaty liturgiczne wykonane przez siostry norbertanki w Żukowie. Wraz z pracami gdańskich brygidek, benedyktynek kongregacji chełmińskiej i warmińskich katarzynek stanowią przykłady wysokiego poziomu artystycznego hafciarstwa zakonnego obszaru dawnych Prus Królewskich. Zetknięcie się z tymi dziełami sztuki, a następnie pojawienie się możliwości bliższego zbadania wyjątkowych paramentów sióstr żukowskich było dla autorki istotnym impulsem do zainteresowania się zagadnieniem roli pracowni klasztornych w kształtowaniu się polskiego hafciarstwa nowożytnego ${ }^{1}$. Eksponowane w Muzeum Parafialnym² przy ponorbertańskim kościele pw. Wniebowzięcia NMP w Żukowie, od 1836 roku parafialnym (utworzonym w 1991 roku, urządzonym w przebudowanych pomieszczeniach gospodarczych dawnego klasztoru - stajni i wozowni z końca XIX w.) przedstawiają dziś jedynie odblask dawnej świetności wyposażenia kościoła klasztornego. Ich kryminalna historia - wielka kradzież w nocy z 25 na 26 sierpnia 1989 roku, podczas której ogołocono żukowski skarbiec (ulokowany w zachodniej części kościoła, nad kruchtą) z wyjątkowo cennych artefaktów ${ }^{3}$ - uwidoczniła, jak wielka jest potrzeba opracowań katalogowych

1. Por. K. Stanilewicz, The role of monastic embroidery workshops in the formation of the early modern Polish embroidery, "Folia Historica Cracoviensia" 22 (2016), s. 467-482.

2. Utworzone w 1991 roku, mieści się w przebudowanych pomieszczeniach gospodarczych dawnego klasztoru - stajni i wozowni z końca XIX wieku.

3. Kradzież odnotowana w aktach policyjnych (Fotokomunikat Biura Kryminalnego Komendy Głównej Milicji Obywatelskiej w Warszawie z dn. 12. września 1989 r.) 
i skłoniła do rozpoczęcia starań o odpowiednią naukową publikację paramentów z pracowni norbertanek w Żukowie. Zachętę do podjęcia się tego zadania stanowił niewątpliwie fakt, że w latach 70. XX wieku powstała dokumentacja zespołu wykonana przez Barbarę Kaźmierską-Latzke. Badaczka opracowała w maszynopisie katalog szat liturgicznych z kościoła ponorbertańskiego, opatrzony czarno-białymi ilustracjami (dziś w zbiorach Narodowego Instytutu Dziedzictwa Narodowego w Gdańsku4), a wcześniej napisała pracę magisterską na ich temat, której streszczeniem jest artykuł opublikowany w niszowym, krótko wydawanym łódzkim biuletynie "Centralne Muzeum Włókiennictwa"5. Znaczenie tego artykułu dla studiów nad warsztatem hafciarskim norbertanek jest duże. Autorka omówiła stan badań oraz dokonała systematyki chronologicznej i analizy artystycznej zabytków, a także dostarczyła przekonujących argumentów na to, że bez wątpienia w Żukowie istniała pracownia klasztorna, w której wykonywano hafty. Dodatkowo ustaliła, chociaż oparła ten pogląd na nielicznych dowodach, że norbertanki „trudniły się także wykonywaniem paramentów dla innych kościołów czy klasztorów i pobierały za to opłaty"6.

Zachowane do dziś paramenty wraz z dokumentacją sporządzoną w latach 70. XX wieku stanowią materiał domagający się rzetelnej publikacji, która byłaby niezbędna z kilku powodów. Po pierwsze pomogłaby w określeniu zakresu oddziaływania warsztatu hafciarskiego sióstr norbertanek i powiązaniu z nim być może większej liczby zabytków, ponadto stanowiłaby istotny punkt odniesienia dla historyków sztuki zajmujących się podobną problematyką - znacząco w tym miejscu należy podkreślić, że do tej pory nie ukazała się ani jedna poważna monografia traktująca o haftach żeńskich zgromadzeń zakonnych dawnej Rzeczypospolitej, mimo że były prowadzone prace badawcze na ten temat ${ }^{7}$. Po drugie pozwoliłaby na stricte naukową

\footnotetext{
i Wojewódzkiego Konserwatora Zabytków (Notatka z dn. 29 sierpnia 1989 r. z lustracji skarbca po włamaniu z dn. 25/26 sierpnia 1989 r.) oraz w lokalnej prasie (Kradzież, która zbulwersowała nie tylko mieszkańców Żukowa. Ogołocono skarbiec, "Wieczór Wybrzeża" z 28.08.1989 r., nr 162, s. 1-2).

4. Zob. B. Kaźmierska-Latzke, Katalog zabytkowych tkanin $i$ haftów w Żukowie, t. 1-2, Poznań 1978 (maszynopis przechowywany w zbiorach Narodowego Instytutu Dziedzictwa Narodowego w Gdańsku).

5. Zob. B. Kaźmierska-Latzke, Hafty, tkaniny jedwabne, płótna lniane drukowane ze skarbca w Żukowie, "Centralne Muzeum Włókiennictwa" 1976, s. 47-110.

6. B. Kaźmierska-Latzke, Hafty, tkaniny..., dz. cyt., s. 48.

7. Wyniki tych badań opracowane zostały albo w maszynopisach, do których dostęp jest ograniczony, albo mają formę przyczynkowych artykułów, por. K. Stanilewicz, The role of monastic embroidery..., dz. cyt., s. 467-468.
} 
analizę wpływu tej wytwórczości na ludowy haft kaszubski, która wydaje się wręcz konieczna ze względu na dużą obecnie liczbę opracowań o charakterze popularnonaukowym, omawiających, co prawda, zabytki żukowskiego kościoła na marginesie rozważań na temat kultury i sztuki kaszubskiej, ale w sposób odbiegający od standardów naukowych i niejednokrotnie z błędami. I choć dziś już rzadziej ich autorzy próbują udowadniać wpływ sztuki ludowej na hafty klasztorne, to jednak wciąż marginalizują rolę zakonnic w kształtowaniu się kaszubskiego ornamentu. Po trzecie wydanie katalogu zbioru mogłoby pomóc w odnalezieniu skradzionych paramentów. Dla uświadomienia wielkości strat warto dodać, że z dziewięćdziesięciu jeden zabytków haftowanych z XVII i XVIII wieku (w tym czterech garniturów szat liturgicznych, siedmiu kompletów ornatowych, trzynastu ornatów, dwunastu antependiów, dwóch alb i jednej tuwalni) zachowało się dziś w Muzeum Parafialnym dwadzieścia szat liturgicznych. Zabytki, które przetrwały, stanowią reprezentatywne przykłady haftu klasztornego, ale to jedynie trzy antependia, cztery ornaty, jedna kapa oraz niewielka liczba przyborów. Szczęśliwie zachowała się także haftowana bielizna liturgiczna w postaci alby i welonu naramiennego.

Zespół haftowanych szat liturgicznych w Żukowie jest interesującym przedmiotem badań z kliku powodów. Przede wszystkim zachowane i udokumentowane zabytki pozwalają prześledzić, w jaki sposób i w jakim stopniu hafciarstwo norbertanek odzwierciedlało przemiany stylowe zachodzące w rzemiośle zawodowym na przestrzeni XVII i XVIII wieku oraz czy ornament uprawiany w warsztacie klasztornym miał znamiona oryginalności. Jednocześnie przeprowadzona w ostatnim czasie inwentaryzacja dowiodła, że nielicznie zachowane obiekty wciąż stanowią bezcenny materiał do poznania dawnych technik hafciarskich, który pozwala na wskazanie rozwiązań charakterystycznych dla pracowni żukowskiej.

Analiza ornamentyki haftów norbertanek prowadzi do wniosku, że maja one związek z tendencjami stylowymi poszczególnych okresów, jednak odznaczają się większym konserwatyzmem. Ten konserwatyzm najsilniej przejawiał się w XVIII wieku w powracaniu do motywów wcześniejszych zwłaszcza do dużych stylizowanych wzorów roślinno-kwiatowych charakterystycznych dla baroku oraz w długim trwaniu ornamentu rokokowego. Barbara Kaźmierska-Latzke stwierdziła, że odrębność w stylu dekoracji wynikała z „izolacji pracowni przyklasztornej od modnych zachodnich kierunków 
haftów dekoracyjnych"8. Bardziej przekonująca wydaje się interpretacja, że konserwatyzm ornamentu wynikał nie z izolacji, lecz z wyboru, ze świadomego trwania przy tradycji, które było cechą właściwą haftu powstającego w kręgach zakonnych. Tak jak symptomatyczna dla polskich haftów nowożytnych była daleko posunięta stylizacja motywów roślinno-kwiatowych, zdradzająca wpływy ornamentyki bliskowschodniej. Bardzo wyraźna jest ona także w paramentach żukowskich, wyjątkowo dobitnie w dekoracji hafciarskiej zachowanej alby i welonu naramiennego pochodzących najpewniej z pierwszej połowy XVIII wieku (il. 1, 2). Motywy wykonane złotą nicią wykazują podobieństwo do haftów tureckich ręczników.

Nawiązując do tendencji stylowych i inspirując się ornamentyką tkanin jedwabnych zachodnioeuropejskich i bliskowschodnich żukowskie norbertanki położyły zasługi w wypracowaniu własnych, oryginalnych wzorów roślinno-kwiatowych w niepowtarzalnej stylizacji i nieco zaskakujących zestawieniach (kwiaty rodzime łączone z motywami roślinno-kwiatowymi zaczerpniętymi z wzorzystych tkanin jedwabnych). W repertuarze motywów znalazły się pospolite kwiaty, przede wszystkim tulipany, goździki, lilie, róże, słoneczniki, irysy i stokrotki zbierane w bukiety, występujące w formie pojedynczych krzaczków, układane jedne nad drugimi lub łączone cienkimi łodygami w esowate układy z głębokimi zakolami. Kompozycje roślinno-kwiatowe stanowią dekorację przeważającej części paramentów żukowskich i dowodzą, że w realizacji tego rodzaju haftów siostry wykazywały dużą biegłość. Rzadko podejmowały się haftowania przedstawień figuralnych (il. 3). Te, po których ślad się zachował, odznaczają się daleko posuniętą nieporadnością przede wszystkim w zakresie rysunku, mniej w zakresie sposobu wykonania. Ich swoisty prymitywizm niepozbawiony jest jednak autentyczności i wdzięku, świadczy o własnej inwencji twórczej hafciarek.

O wyjątkowości tych paramentów przesądza bogactwo i różnorodność w zastosowaniu technik hafciarskich. Siostry wykorzystywały nici złote i srebrne oplatane, ale także lamelki, bajorki i cekiny, kładły je bezpośrednio na tkaninie lub stosowały wypukłe podkłady, bardzo często wypełniały płaszczyzny motywów nawet kilkoma rodzajami nici metalowych układanymi w motyw siatki. Niekiedy, najczęściej jako uzupełnienie dla dekoracji z nici metalowych, wprowadzały nici jedwabne kolorowe, zwykle przez zastosowanie ściegów satynowego i supełkowego. Tylko nieliczne szaty liturgiczne

8. B. Kaźmierska-Latzke, Hafty, tkaniny..., dz. cyt., s. 58. 


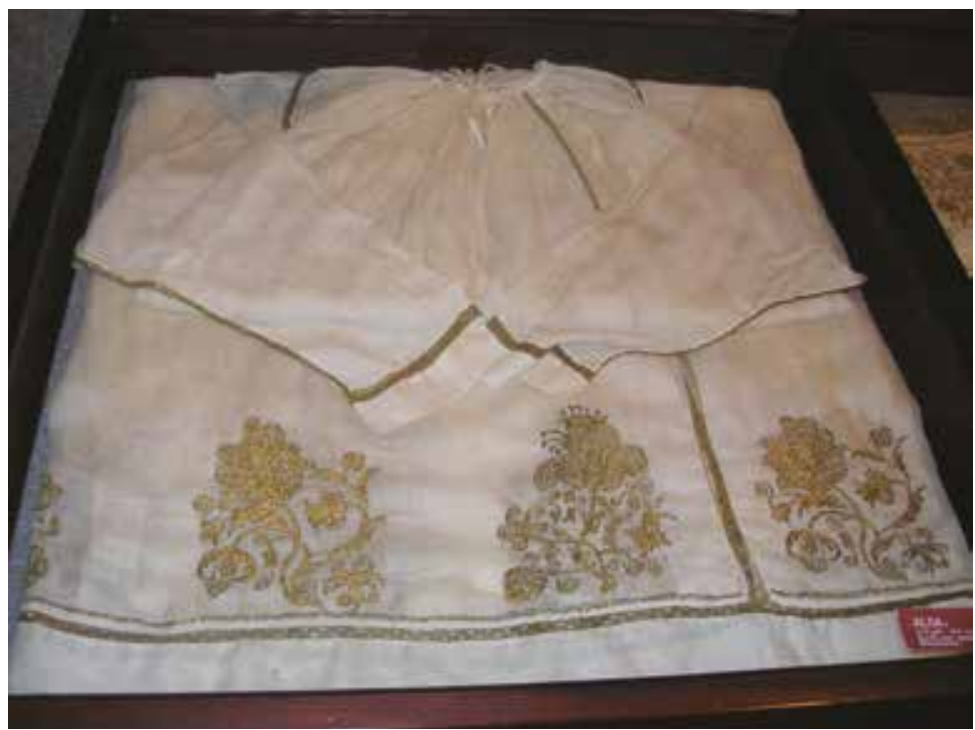

1. Alba. Klasztorny warsztat hafciarski sióstr norbertanek w Żukowie, 1. poł. XVIII w., kościół parafialny pw. Wniebowzięcia NMP w Żukowie. Fot. Karolina Stanilewicz

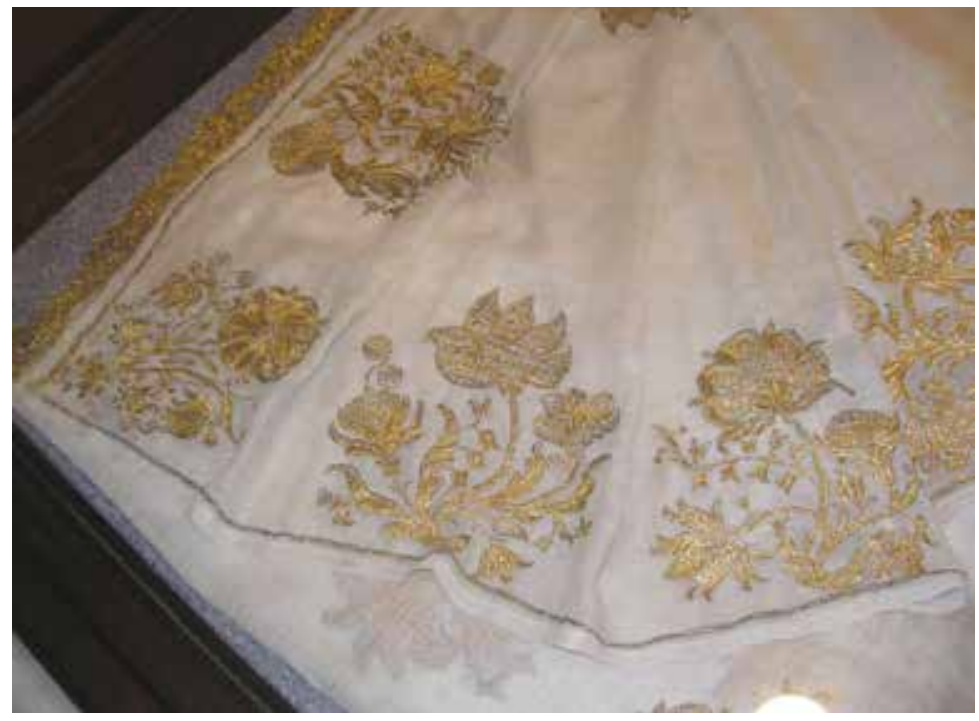

2. Fragment welonu naramiennego. Klasztorny warsztat hafciarski sióstr norbertanek w Żukowie, 1. poł. XVIII w., kościół parafialny pw. Wniebowzięcia NMP w Żukowie. Fot. Karolina Stanilewicz 
3. Bursa. Klasztorny warsztat hafciarski sióstr norbertanek w Żukowie, 1 ćw. XVIII w., kościół parafialny pw. Wniebowzięcia NMP w Żukowie. Fot. Karolina Stanilewicz

4. Antependium czerwone. Klasztorny warsztat hafciarski sióstr norbertanek w Żukowie, 1767 r., kościół parafialny pw. Wniebowzięcia NMP w Żukowie. Fot. Karolina Stanilewicz
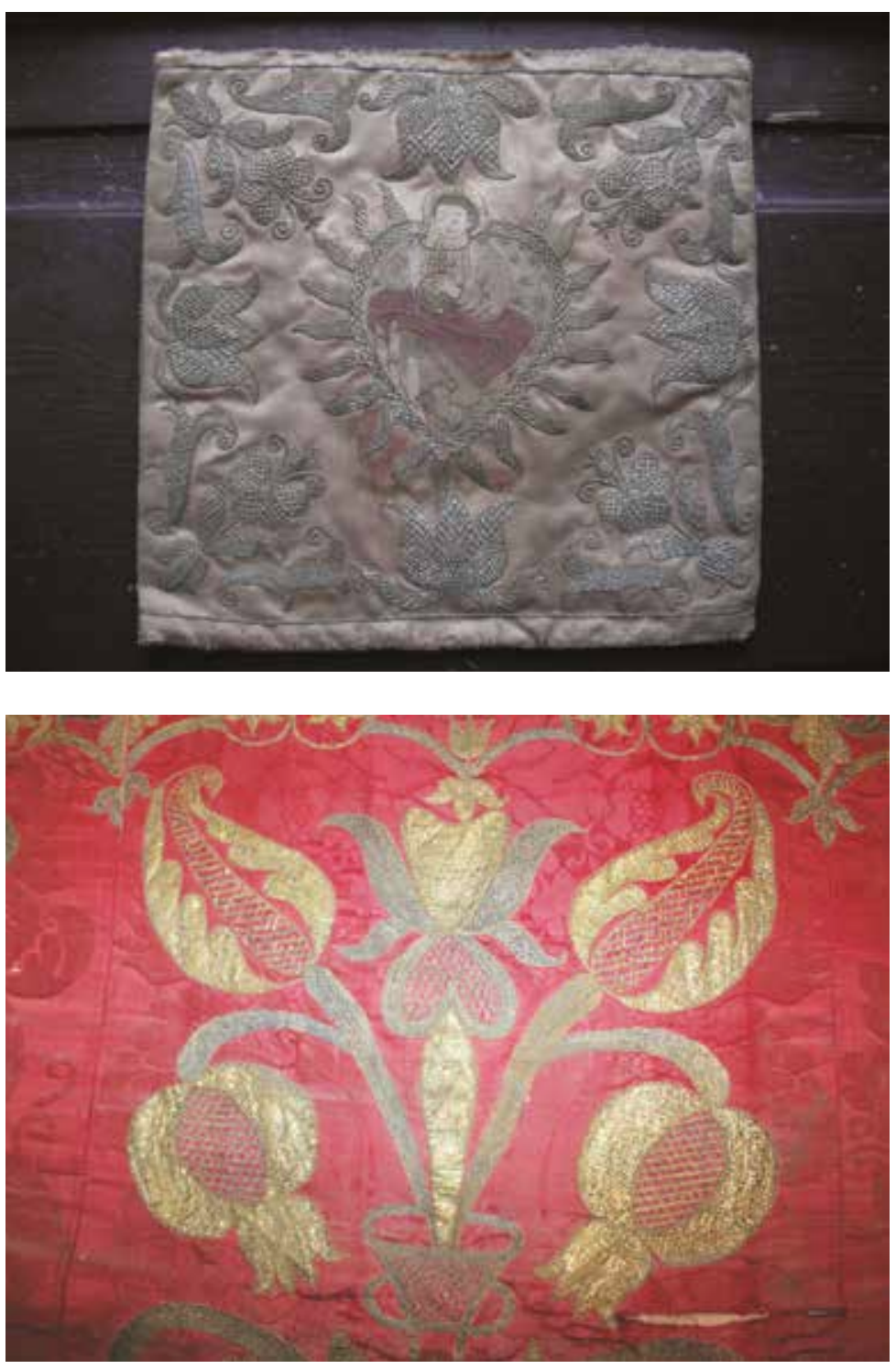
ozdobione zostały w technice aplikacji z kolorowych atłasów. Mimo że wszystkie wymienione techniki były powszechnie stosowane w hafciarstwie nowożytnym, to sposób ich użycia i łączenia zdradza cechy szczególne tego konkretnego warsztatu.

Hafty pomorskich norbertanek stanowią wyjątkowe dziedzictwo. Rzadko które zabytki sztuki nowożytnej mają w sobie tyle świeżości i wdzięku. Ich znaczenie jest tym większe, że wykazują cechy wspólne z polskimi wyrobami tkackimi, które zyskały miano swojszczyzny (szpalery, kilimy, kobierce) ${ }^{9}$ i że znacząco oddziałały na sztukę kaszubską.

Norbertanki od 1772 do 1834 roku, czyli od sekularyzacji klasztoru do jego kasaty, były w trudnej sytuacji. Władze pruskie odebrały im majątek i zakazały prowadzenia nowicjatu oraz przyjmowania nowych członkiń. Siostry pozostały w Żukowie aż do śmierci ostatniej kanoniczki w 1862 roku i zajęły się kształceniem dziewcząt kaszubskich z warstw niższych. Dzięki ich aktywności wieś wyrosła na jeden z trzech ośrodków haftu kaszubskiego ${ }^{10}$. Jedną z ostatnich uczennic norbertanek była Marianna Ptach z domu Okoniewska, babka dwóch hafciarek - Zofii i Jadwigi Ptach, które przyczyniły się do odrodzenia tradycji hafciarskiej w Żukowie ${ }^{11}$. Siostry Ptach zaczęły uczyć tego rzemiosła w latach 30. XX wieku, przed wojną ich zespół skupiał trzydzieści kobiet. Po wojnie działalność była kontynuowana, a jej efekty można podziwiać między innymi w Muzeum Parafialnym w Żukowie. Prace te uznane zostały za najsubtelniejsze wśród haftów kaszubskich.

Przekonujące są, aczkolwiek wymagają pogłębienia i wskazania większej liczby przykładów, analizy przeprowadzone przez badaczy sztuki ludowej na Kaszubach - Tadeusza Seweryna i Bożenę Stelmachowską - którzy przedstawili bezpośrednie analogie pomiędzy dekoracją uprawianą przez

9. Por. J. Pagaczewski, Gobeliny polskie, Kraków 1929, s. 91; B. Kaźmierska-Latzke, Hafty, tkaniny..., dz. cyt., s. 59 .

10. Do ważniejszych opracowań na temat historii kościoła i klasztoru żukowskiego oraz jego zabytków należą: F. K. Okroy, Dzieje klasztorów norbertańskich w Żukowie, Toruń 1951 (Żukowo 2010); W. Szołdrski, Miscellanea żukowskie, Kraków 1957; A. Grzędzicki, Żukowo, Gdańsk 1989; Dzieje Żukowa, red. B. Śliwiński, Żukowo 2003; Norbertańska siła Kaszub, red. A. Groth, E. Pryczkowski, Banino 2011; J. Belgrau, Norbertańskie dzieje Żukowa, Żukowo 2012; Kościół Mariacki w Żukowie. Zabytki sakralnej kultury artystycznej dawnego klasztoru Norbertanek, tekst: K. M. Kowalski, Żukowo 2012; E. Pryczkowski, Leksykon Ziemi Żukowskiej, Banino-Żukowo 2012.

11. Zob. Bedeker kaszubski, red. R. Ostrowska, I. Trojanowska, Gdynia 1962, s. 116, 252254; A. Grzędzicki, Żukowo, dz. cyt., s. 63-68; E. Pryczkowski, Leksykon..., dz. cyt., s. $83-84$. 
norbertanki a ornamentem występującym na kaszubskich wyrobach rzemiosła artystycznego ${ }^{12}$. W hafcie kaszubskim związki te przejawiają się w powtarzaniu w podobnej stylizacji jak na paramentach żukowskich kwiatów lilii, tulipana, goździka i owoców granatu, łączonych z motywem kosza lub serca w kratkę. Ilustrują je zachowane do dziś zabytki, na przykład antepedium czerwone (1767 r.) z tulipanami, goździkami, owocami granatu oraz motywami kosza i przypominającym kaszubskie serca (il. 4) czy boki ornatu białego aplikowanego kolorowymi atłasami (1. ćw. XVIII w.) ozdobione w dolnej części dużą stylizowaną lilią (il. 5,6). Odpowiednie omówienie tych zależności nie będzie możliwe bez wcześniejszego przeprowadzenia analizy porównawczej paramentów żukowskich z zachowanymi haftami benedyktynek żarnowieckich. Trzeba pamiętać, że konwenty te utrzymywały stały kontakt i wzajemnie na siebie oddziaływały. Już przy wstępnym przyjrzeniu się tym dziełom odnaleźć można bardzo wiele podobieństw, ale i dają się zauważyć swego rodzaju warsztatowe odrębności, zarówno w zakresie techniki wykonania, jak i repertuaru wykorzystanych motywów.

Na tym nie kończą się perspektywy badawcze podjętego zagadnienia. Jak wspomniano wyżej, Kaźmierska-Latzke sformułowała bardzo prawdopodobną, lecz słabo udowodnioną tezę, że żukowskie siostry wytwarzały paramenty na zamówienia z zewnątrz za stosowną opłatą. Za Annales Monasterii Oliviensis wymieniła ornat z dalmatykami uszyte z białego adamaszku haftowanego we wzór nićmi złotymi i srebrnymi, zamówione u norbertanek przez cystersów oliwskich, za które w kwietniu 1739 roku zapłacono 1173 floreny ${ }^{13}$. W ostatnim czasie znalazł się jeszcze jeden ciekawy dowód na to, że do

12. Szczególnym zainteresowaniem badaczy cieszyły się czepce kaszubskie, tzw. złotogłowia lub złotnice, które żukowskie norbertanki haftowały najpewniej dla zarobku, a jednocześnie uczyły tego rzemiosła dziewczyny wiejskie, zob. T. Seweryn, Kaszubskie złotogłowie i nowe hafty wdzydzkie, Lwów 1929 s. 10-14 (Towarzystwo Ludoznawcze, Seria 2, t. 8); E. Frankowski, Złotogłowie kaszubskie, „Polska Sztuka Ludowa" 8 (1954) nr 3, s. 149; B. Stelmachowska, Sztuka ludowa na Kaszubach, Poznań 1937, s. 54-75; B. Kaźmierska-Latzke, Hafty, tkaniny..., dz. cyt., s. 50. Istotne wnioski dotyczące oddziaływania żeńskich zgromadzeń zakonnych na pomorską sztukę ludową zawarła w swoim artykule Maria Szczypkówna, zob. M. Szczypkówna, Hafty żarnowieckie, „Zeszyty Naukowe Uniwersytetu im. A. Mickiewicza w Poznaniu. Historia Sztuki" 1960 z. 2, s. 159-227.

13. Zob. P. Czaplewski, Annales Monasterii Oliviensis ord. Cist. Aetate posteriores, Toruni 1916, (cz. 1), s. 501. O darowaniu lub sprzedawaniu szat wykonanych w Żukowie innym kościołom dowiadujemy się także z innych źródeł, m.in. za pośrednictwem ks. Jakuba Fankidejskiego, zob. J. Fankidejski, Klasztory żeńskie w dyecezyi chełmińskiej, Pelplin 1883, s. 47. 

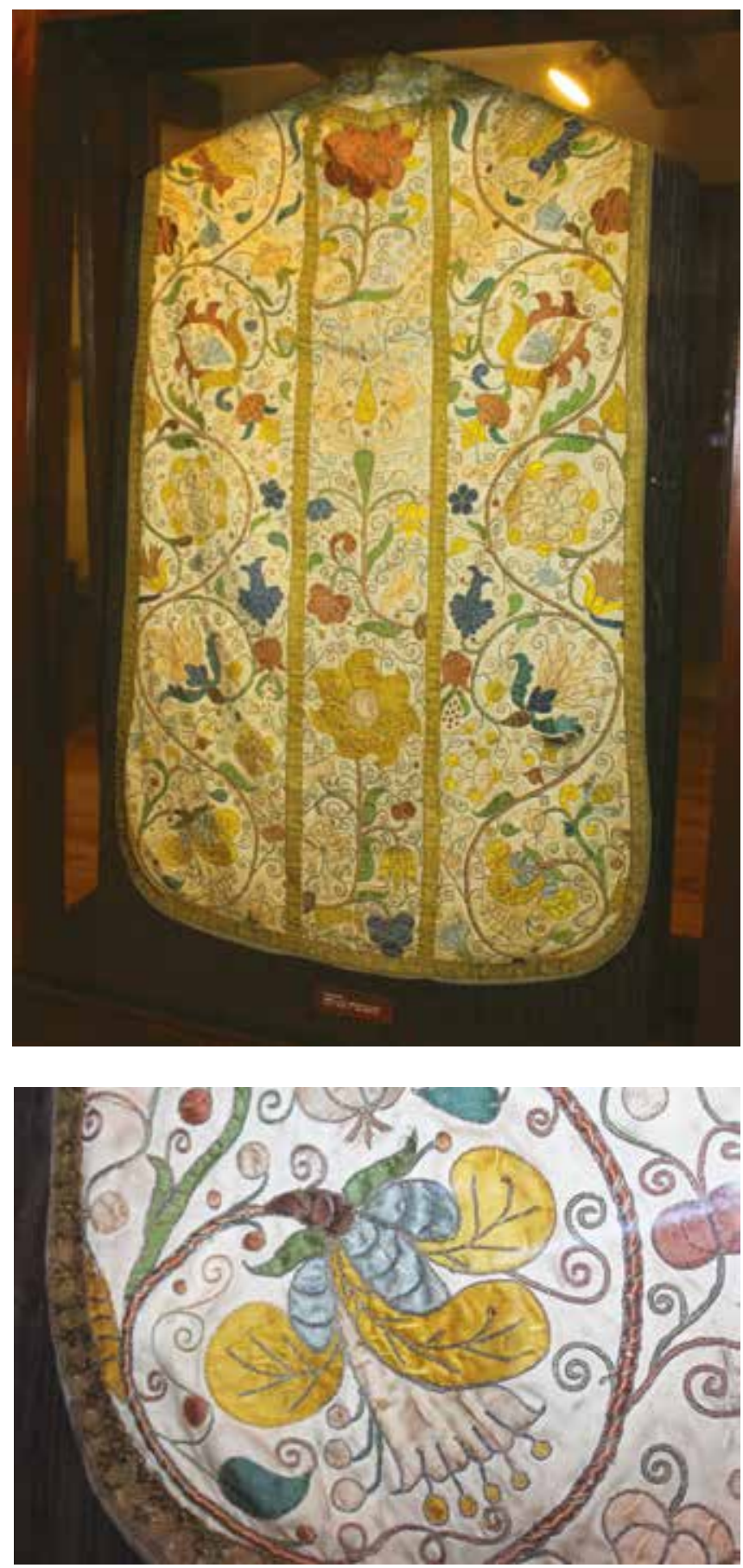

5. Ornat biały. Klasztorny warsztat hafciarski sióstr norbertanek w Żukowie, 1. ćw. XVIII w., kościół parafialny pw. Wniebowzięcia NMP w Żukowie. Fot. Karolina Stanilewicz
6. Fragment dekoracji boków ornatu białego. Klasztorny warsztat hafciarski sióstr norbertanek w Żukowie, 1. ćw. XVIII w., kościół parafialny pw. Wniebowzięcia NMP w Żukowie. Fot. Karolina Stanilewicz 
warsztatu klasztornego w Żukowie spływały prestiżowe zlecenia. Jest nim zachowany w Muzeum Archidiecezjalnym w Gdańsku-Oliwie ornat opata klasztoru Cystersów w Oliwie Aleksandra Kęsowskiego (1641 - 1667), wykonany najpóźniej przez 1667 rokiem. Ustalenie fundacji umożliwił wyhaftowany w dolnej części kolumny tyłu kartusz herbowy z godłem Poraj i literami AB(atus) O(liviensis) A(leksander) K(ęsowski) ${ }^{14}$. Na jego związek z pracownią klasztorną wskazują cechy wspólne z dekoracją ornatu białego, do 1989 roku przechowywanego w skarbcu w Żukowie ${ }^{15}$. Te dwa przykłady stanowią wystarczającą przesłankę, aby sądzić, że siostry sporządzały szaty liturgiczne dla męskich zgromadzeń zakonnych na Pomorzu. Co ciekawe, istnieją obiecujące wzmianki o tym, że w Żukowie powstawały również haftowane paramenty dla kościołów z innych obszarów Rzeczypospolitej ${ }^{16}$. Skoro - jak twierdzi ks. Franciszek Ksawery Okroy - paramenty u norbertanek nabywali biskupi włocławscy, to tym bardziej zamawiano je u nich dla świątyń w Pelplinie, Oliwie czy Kartuzach, które utrzymywały z klasztorem żukowskim bliższe stosunki ${ }^{17}$. Wydaje się, że wnikliwa kwerenda w kościołach pomorskich oraz Muzeum Diecezjalnym w Pelplinie, Muzeum Archidiecezjalnym w Gdańsku-Oliwie i Muzeum Narodowym w Gdańsku mogłaby przynieść owocne rezultaty.

Bogate hafty paramentów żukowskich nie tylko mówią o znaczeniu i zamożności klasztoru Norbertanek, ale przede wszystkim są świadectwem znaczącego wkładu dziedzictwa zakonnego w tworzeniu kultury na Pomorzu.

14. Zachowany ornat błędnie utożsamiony z opisanym w Annales Monasterii Oliviensis przez Beatę Sztyber, autorkę jedynych do tej pory opracowań na jego temat, zob. Ornamenta Ecclesiae Poloniae. Skarby sztuki sakralnej wiek X-XVIII, kat. wyst., Zamek Królewski w Warszawie, 15.05-8.08.1999, red. P. Mrozowski, A. Badach, Warszawa 1999, poz. LXXI (oprac. B. Sztyber), s. 148; B. Sztyber, Klasztorny zbiór tkanin żukowskich, ze szczególnym uwzględnieniem tzw. ornatu Świętopełka, w: Norbertańska siła..., dz. cyt., s. 77-78, il. 1-2.

15. Zob. B. Kaźmierska-Latzke, Katalog zabytkowych..., dz. cyt., t. 1, poz. 64, s. 78-79, t. 2 , poz. 64 .

16. Ksiądz Franciszek Ksawery Okroy wzmiankuje m.in., że w 1879 roku przy naprawie zabytkowych paramentów z katedry włocławskiej znaleziono w bursach i palkach listy z drugiej połowy XVII wieku, pisane przez różne osoby do przeorysz klasztoru Norbertanek w Żukowie, zob. F. K. Okroy, Dzieje klasztorów norbertańskich..., dz. cyt., s. 105-106.

17. Ponadto ks. Franciszek Ksawery Okroy wspomina, że po kasacie klasztoru, jeszcze w latach 1857-1859, paramenty z Żukowa za staraniem biskupa sufragana i generalnego wikarego kurii biskupiej z Pelplina Jerzego Jeschke trafiały do nowo wybudowanych kościołów w Bysławiu, Nidzicy, Ostródzie, Działdowie i Nowym Porcie, zob. F. K. Okroy, Dzieje klasztorów norbertańskich..., dz. cyt., s. 106. 
Celem tego artykułu było zwrócenie uwagi, jak wielkich dopuszczono się zaniedbań w zakresie ochrony i dokumentacji tej niezwykłej spuścizny i jak ciekawe problemy badawcze ona przed nami stawia. 


\section{Bibliografia}

Bedeker kaszubski, red. R. Ostrowska, I. Trojanowska, Gdynia 1962.

Belgrau J., Norbertańskie dzieje Żukowa, Żukowo 2012.

Czaplewski P., Annales Monasterii Oliviensis ord. Cist. Aetate posteriores, CZ. 1, Toruni 1916.

Dzieje Żukowa, red. B. Śliwiński, Żukowo 2003.

Fankidejski J., Klasztory żeńskie w dyecezyi chełmińskiej, Pelplin 1883.

Frankowski E., Złotogłowie kaszubskie, „Polska Sztuka Ludowa" 8 (1954)

nr 3, s. 148-161.

Grzędzicki A., Żukowo, Gdańsk 1989.

Kaźmierska-Latzke B., Hafty, tkaniny jedwabne, płótna lniane drukowane ze skarbca w Żukowie, "Centralne Muzeum Włókiennictwa" 1976, s. $47-110$.

Kaźmierska-Latzke B., Katalog zabytkowych tkanin i haftów w Żukowie, t. 1-2, Poznań 1978 (maszynopis przechowywany w zbiorach Narodowego Instytutu Dziedzictwa Narodowego w Gdańsku).

Kościół Mariacki w Żukowie. Zabytki sakralnej kultury artystycznej dawnego klasztoru Norbertanek, tekst: K. M. Kowalski, Żukowo 2012.

Norbertańska siła Kaszub, red. A. Groth, E. Pryczkowski, Banino 2011.

Okroy F. K., Dzieje klasztorów norbertańskich w Żukowie, Toruń 1951 (Żukowo 2010).

Ornamenta Ecclesiae Poloniae. Skarby sztuki sakralnej wiek X-XVIII, kat. wyst., Zamek Królewski w Warszawie, 15.05.-8.08.1999, red. P. Mrozowski, A. Badach, Warszawa 1999.

Pagaczewski J., Gobeliny polskie, Kraków 1929.

Pryczkowski E., Leksykon Ziemi Żukowskiej, Banino-Żukowo 2012.

Seweryn T., Kaszubskie złotogłowie i nowe hafty wdzydzkie, Lwów 1929 (Towarzystwo Ludoznawcze, Seria 2, t. 8).

Stanilewicz K., The role of monastic embroidery workshops in the formation of the early modern Polish embroidery, "Folia Historica Cracoviensia" 22 (2016), s. 467-482.

Stelmachowska B., Sztuka ludowa na Kaszubach, Poznań 1937. 
Szczypkówna M., Hafty żarnowieckie, „Zeszyty Naukowe Uniwersytetu

im. A. Mickiewicza w Poznaniu. Historia Sztuki" 1960, z. 2, s. 159-227.

Szołdrski W., Miscellanea żukowskie, Kraków 1957. 


\section{Abstrakt}

Karolina Stanilewicz

Zabytkowe hafty norbertanek żukowskich.

Stan badań po czterdziestu latach

\author{
Słowa kluczowe: \\ hafciarstwo, \\ warsztaty \\ klasztorne, szaty \\ liturgiczne, \\ Żukowo, \\ norbertanki
}

Haftom sióstr norbertanek z Żukowa, najciekawszym przykładom tego rodzaju rzemiosła artystycznego na obszarze dawnych Prus Królewskich, poświęcono jak dotąd bardzo niewiele miejsca w literaturze fachowej. Doczekały się jednego tylko poważnego artykułu autorstwa Barbary Kaźmierskiej-Latzke, niestety mało znanego, opublikowanego w 1976 roku w niszowym, krótko wydawanym łódzkim biuletynie „Centralne Muzeum Włókiennictwa". Pozostałe opracowania, głównie o charakterze etnograficznym i popularnonaukowym, wspominają jedynie zabytki z żukowskiego kościoła na marginesie rozważań na temat haftu kaszubskiego. Ich autorzy na szczęście już coraz rzadziej próbują udowadniać wpływ sztuki ludowej na hafty klasztorne, mimo to jednak wciąż marginalizują rolę zakonnic w kształtowaniu się kaszubskiego ornamentu. W tej sytuacji niezbędna wydaje się rzetelna publikacja na temat haftów wykonanych przez norbertanki, tym bardziej że liczba zachowanych obiektów wciąż się zmniejsza i coraz więcej znamy już tylko ze zdjęć archiwalnych. Z dziewięćdziesięciu jeden zabytków haftowanych przetrwało w parafii pw. Wniebowzięcia NMP w Żukowie jedynie dwadzieścia jeden paramentów (większość skradziono w 1989 roku). Wydanie katalogu szat liturgicznych z pracowni norbertanek z uwzględnieniem dokumentacji fotograficznej sprzed 1989 roku mogłoby pomóc w odnalezieniu skradzionych dzieł, a opracowany i przeanalizowany materiał stanowiłby znakomity punkt odniesienia dla badaczy zajmujących się podobną problematyką. Jednocześnie pozwoliłoby to na bliższe określenie zakresu oddziaływania warsztatu hafciarskiego sióstr norbertanek i powiązanie z nim większej liczby zabytków. 


\section{Abstract}

Karolina Stanilewicz

Antique Embroidery of Norbertines from Żukowo. The State of Research after Thirty Years

It has been written so far very little about the antique embroideries of Norbertines from Żukowo in the professional literature. And they belong to the group of the most interesting examples of this kind of artistic craft in the area of the former Royal Prussia. There was only one major article about them written by Barbara Kaźmierska-Latzke. Unfortunately it was not so well known as it was published in the niche and issued for a short time bulletin of Łódź "Central Museum of Textiles." Other studies which have mainly ethnographic and popular science character mention the works of art from church in Żukowo but only on the sidelines of deliberations on Kashubian embroidery. Their authors are trying to prove the influence of folk art on monastic embroidery thankfully less and less, but they still marginalize the role of nuns in the formation of the Kashubian ornament. In this situation a reliable publication of embroideries made by the Norbertines seems necessary, especially that their state of preservation is still getting worse and many of them we know today only from the archival photos. From ninety one embroidered objects in the parish church in Żukowo only twenty one vestments remained preserved until today (most of them were stolen in 1989). Edition of the catalogue of vestments originating from the Norbertines workshops including the photographic documentation before the year 1989 could be helpful in finding these stolen works. The material developed and analyzed in such a catalogue would provide an excellent reference point for researchers dealing with similar issues. At the same time it would allow for closer designation of the influence range of the Norbertines monastic workshops and associate with it perhaps a greater number of works.
Keywords: embroidery, monastic workshops, vestments, Żukowo, Norbertines 